測定を当院に導入された 2 台の FCR7000について行う.

〔結果〕タイムスケール法 (mAs 可変)により IP 入射 線量を調節した。測定はテストモードの最大值固定でラ チチュードを可変, また FIX モードで読み取り感度を可 変する方法で行った，2 台の FCR7000 は共に特性曲線 の形状は変わらなかった。またわれわれは CR システム においてIPのフェーディング現象が比較的短時間内で も存在しそれが物理測定データに少なからず影響してい ることを確めた。そのフェーディングにより CR システ 么の特性曲線の形状が変化する危険性がありまた収録モ ードやラチチュードによってはその影響が無視できない。 61. テンソースキャンの基礎的検討

いわき市立総合鈸城共立病院

○伊藤 幹・安達伸也・田中邦夫 今野広一・林 敏幸・菅原達夫 佐藤知好

〔目的〕デンソースキャンは，21段の階段露光が行え るセンシトメータ(S44) と, コンピュータを内蔵し, 濃 度值・特性曲線・平均階調度などを自動的に計算する機 能を持つデンシトメータ (D44) から構成される. 今回, 当院において，このシステムを使用する機会を得たので， WEJEX および強度法との比較検討を行った。

〔結論〕(1)特性曲線の形状において，レギュラ系で高 濃度付近で差が認められ, オルソ系で強度法と一致した。 (2)低濃度から高濃度まで再現性に優れる. (3)キャリブレ ーションの設定値を変えても特性曲線の形状に大きな差 はない. (4) PC-9801 とのオンライン化をはかり, データ 処理が容易になった。

\section{5 施設でのウィナースペクトルの測定}

東北画像研究会

$\begin{aligned} \text { 山形大学 } & \text { 江口陽一 } \\ \text { 東北大学 } & \text { 阿部養悦 } \\ \text { NTT 東北 } & \text { 大久敏弘 } \\ \text { 磐城共立 } & \text { 今野広一 } \\ \text { 福島労災 } & \text { 後藤正美 }\end{aligned}$

〔目的〕東北地区でウィナースペクトルを測定してい る 5 施設（磐城共立, NTT 東北, 東北大学, 福島労災, 山形大学）において, 同一試料を測定し, 各施設の測定 の現状と施設間比較について検討した。

〔結果〕1）各施設の測定条件は，走查速度，デー夕 数, 拡散光濃度への変換方法などで多少異なるが, 全体 的に大きな差はない.2）各施設で得られたウィナースペ クトルには差が見られた。 ウィナースペクトルの測定精 度に影響する因子は非常に多く, 今回の施設間の差がハ
ードウェアにあるのか，それともソフトウェアにあるの かを推定することは現在困難であった. 今後これらを検 討し，施設間の差を小さくして行きたい.

\section{座長集約}

このセッションはデジタルイメージング装置の特性曲 線に関する演題が 2 題, X線フィルム特性曲線に関する 演題が 2 題, ウィナースペクトルに関する演題が 1 題で あった，演題58はDSA 装置の特性曲線をブートストラ ップ法にて求めたという内容であった。 発表中にDSA 装置の感度をピクセル值512を得られる照射 $\mathrm{X}$ 線量で求 めたという内容のものがあった.この方法による他装置 との比較など, 今後の発表を期待したい. 演題59はブー トストラップ法による特性曲線をパーソナルコンピュー 夕により求め日常の装置管理に応用したという内容の発 表であった，特性曲線の近似方法にやや問題があるよう なので今後ひきつづき検討してほしい. 演題60は CRの オーバーオール特性曲線をタイムスケール法によって求 めたとの発表であった。発表の中にイメージングプレー トの短時間におけるフェーディング現象が存在するとい う内容の発表があった，基礎的検討にとどまらず，さら に 1 ステップ上の発表を期待したい. 演題 61 はデンソス キャンシステムによる特性曲線と他の感光計による特性 曲線, さらに強度法による特性曲線との比較を行ったと いう内容のものであった. 今回の結果を臨床に生かし応 用してほしい. 演題62は東北地方でのウィナースペクト ル測定の現状についての発表であった. 各施設の測定値 に大きなばらつきにがみられ, 今後の原因究明, 検討に 期待したい。

\section{フラッシュ $\mathbf{X}$ 線（I）}

座長 太田 温（東北大学医療技術短期大学部）

\section{3. 三極管を用いた冷陰極定常 X 線装置}

\author{
岩手大物理
}

O佐藤英一・磯部 寛
岩手医大中放
佐々木勝秋・秋津武志・玉川芳春
岩手医大 RI 及川昭弘
岩手医大放科 柳沢 融
東北大放射部 有馬宏寧

本研究では冷陰極三極管を有する定常 X線装置を試作 し, 高出力で安定したX線を得ることを目的としている. 本装置は高電圧電源 2 台 (正負 $\pm 100 \mathrm{kV}$ ), 放電制御用抵 抗，およびX線管などより成る。管はタングステン製の 棒状陽極, リング状陰極, およびテーパ形のリング状放 電極より成る.放電極はX線照射口の内側に位置し，陰 